\title{
A MÚZEUMPEDAGÓGIA ÉS A TEHETSÉGGONDOZÁS LEHETŐSÉGEI EGY VIRTUÁLIS MÚZEUMBAN
}

\author{
Szerzők: \\ Mező Katalin (Ph.D.) \\ Debreceni Egyetem \\ Mező Ferenc (Ph.D.) \\ Eszterházy Károly Egyetem \\ E-mail address: \\ kata.mezo1@gmail.com
}

\section{Lektorok:}

Balogh Ágota (Ph.D.)

Gál Ferenc Egyetem

Ildikó Pšenáková (Ph.D.)

Trnavská Univerzita (Slovakia)

...és további két anonim lektor

Mező, K. és Mező, F. (2020). A múzeumpedagógia és a tehetséggondozás lehetőségei egy virtuális múzeumban. Különleges Bánásmód, 6. (3). 89-99. DOI 10.18458/KB.2020.3.89

\begin{abstract}
Absztrakt
Jelen tanulmány az alapítás és fenntartás, a látogatói élmények, a biztonság és a múzeumi élmények szempontjából hasonlítja össze a valódi és a virtuális múzeumokat. A tanulmány végén egy virtuális múzeum pedagógiai (például: tehetséggondozásbeli) lehetőségeit körvonalazó példák találhatók az oktatás, a képesség-, személyiség és módszertani fejlesztés, illetve a teljesítményre ösztönzés aspektusából.

Kulcsszavak: múzeum, virtuális múzeum, pedagógia, tehetség

Diszciplinák: pedagógia, informatika
\end{abstract}

\begin{abstract}
THE POSSIBILITIES OF MUSEUM PEDAGOGY

AND TALENT DEVELOPMENT IN A VIRTUAL MUSEUM

The present study compares the real and the virtual museums from viewpoints of foundation and operating, visitor experiences, safety and security, and museum services. At the end of the study, there are examples of the pedagogical (e.g. talent developmental) possibilities of a Virtual Museum from the aspect of education, development of cognitive abilities and personality, and the methodological development and the incentive of achievement.
\end{abstract}

Keywords: museum, virtual museum, pedagogy, talent

Discipline: pedagogy, IT 
A 21. század alapkövetelménye, hogy a digitális és virtuális közösségben felnövekvő nemzedékek számára is biztosítsuk a kultúrabefogadás lehetőségét. Ehhez szükség van arra, hogy olyan interdisziplináris és intermediális innovációkat hozzunk létre, melyek lehetôvé teszik a kultúra- és tudományközvetítést az egyének számára, s emellett kielégítik a digitális nemzedék fokozott élménykereső magatartásából adódó újdonságigényt is. Ennek egyik formája lehet a jelen tanulmányban megjelenő virtuális múzeumi közeg, mely céljaiban és tartalmában beteljesíti a hagyományos múzeum küldetését, s a digitális technológiák kínálta (virtuális)tér- és időbeli szabadság kihasználásának lehetôségével új, szórakoztató, modern lehetőséget nyújt a múlt, a jelen és a jövő értékeinek megőrzéséhez. A virtuális múzeumok egyben az élménypedagógia eszközei is lehetnek.

\section{A múzeum}

„Múzeum” szavunk a görög „museion” szóból ered, mely a „múzsáknak szentelt berek”, a „múzsák szentélye" jelentéssel bír, és eredetileg bármilyen olyan helyet jelentett, melyet az ókorban a múzsák tiszteletére állítottak fel.

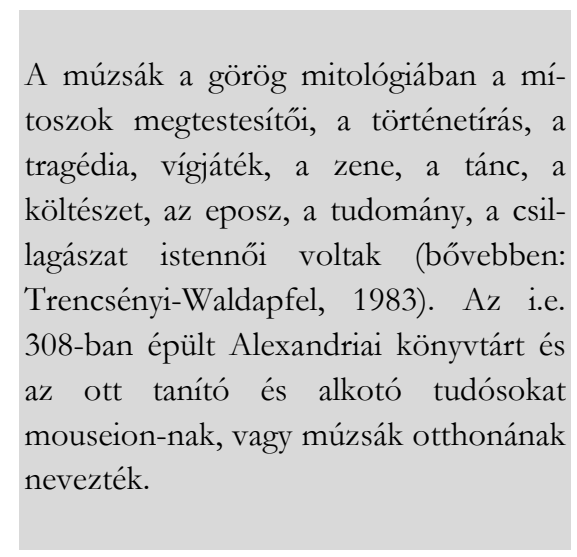

Az első múzeumok a hellénizmus korában $(\mathrm{kb}$. i.e. 323 - i.e. 30 között) jelentek meg, s szellemi hatásukat tekintve valószínúleg a kor legfontosabb intézményei voltak. A múzeumok, nem egyszerű kultuszhelyként funkcionáltak, hanem már ekkor betöltötték, a napjainkra jellemző kultúra- és tudományközvetítő szerepüket. Az Alexandriai Museion volt az első olyan intézmény, amelyet a tudományos kutatás és a szellemi örökség megőrzésének céljából hoztak létre (Swiderkowna, 1981).

A múzeum „olyan tudományos intézmény, amely a természet és a társadalom fejlődésének, történeti alakulásának tárgyait, ill. egyéb dokumentumait (film, fénykép, rajz, hangfelvétel), anyagát gyüjti, megőrzi, feldolgozza, s e tevékenysége eredményeit kiállításokon, kiadványokban bocsátja a szaktudományok és a népmúvelés rendelkezésére" (Ortutay, 1980). Lényegében hasonló, ám funkcionális feladatok tekintetében bővebb meghatározást találhatunk a muzeális intézményekről, a nyilvános könyvtári ellátásról és a közmûvelődésről szóló 1997. évi CXL. törvény 42. §-ában, miszerint „a múzeum a kulturális javak tudományosan rendszerezett gyűjteményeiből álló muzeális intézmény, amely a kulturális javakat és a szellemi kulturális örökség elemeit tudományos, örökségvédelmi, oktatási és ismeretátadási céllal gyújti, megőrzi, feldolgozza, kutatja és kiállítja, továbbá egyéb formákban közzé teszi. Tevékenységével elősegíti a természeti, társadalmi, múvészeti, kulturális és tudományos összefüggések kutatását, megértését, nyomon követi azok jelenkori változásait és folytonos művelődésre ösztönöz." Noha az 1997. évi CXL. törvény módosítására 2012. évi CLII. törvényben, valamint a 2017. évi LXVII. törvényben sor került, azonban a módosítások a 1997. évi CXL. törvény 42.§-ában közölt múzeummeghatározást nem érintették.

A múzeum feladatát tekintve tehát a kulturális javak gondozásával (gyarapításával, nyilvántartásával és állományvédelmével); tudományos feldolgozással és publikálással, valamint hozzáférhetôvé tétellel (állandó és időszakos kiállítások rendezésével, közművelődési és múzeumpedagógiai programok és kiadványok biztosításával, a kultu- 
rális javak digitalizálásával, a kutatási tevékenységek biztosításával) foglalkozik.

A múzeumi feladatok ellátása tekintetében egyre több olyan korszerú program jelenik meg, melyek a múzeum szerepének átértelmeződését közvetítik. A múzeum mára már sok esetben nem csak egyszerú, rideg gyújteménytár, vagy tárház, hanem egyfajta interaktív bemutatóközpont, amely gyakran helyet ad az iskolai formális oktatást kiegészító, élményszerű informális oktatás megvalósulásának.

\section{Múzeumpedagógia}

A múzeumpedagógia a múzeumokban, skanzenekben (falumúzeumokban) lezajlódó közvetlen megfigyelésre épülő élménypedagógiai tevékenység. „A múzeumpedagógiai foglalkozások célja, az adott múzeumi tematika alapján szervezett gyakorlati feladatok megoldása által a magas szintú kultúra, a múvészet megszerettetése és egy művészetkedvelő felnőtt generáció felnevelése” (Mező, 2015, 89.). A múzeumpedagógia a legkülönbözőbb korosztályok és a múalkotások közötti természetes viszony kialakítására törekszik.

Az Európai Bizottság által 2000-ben kiadott Memorandum az életen át tartó tanulásról (Memorandum, 2000) alapján a múzeum nem-formális oktatási tanulási színtér, azaz szervezett, de a formális oktatási rendszeren kívül történő tanulási helyszín és folyamat, ahol a képzés általában egy meghatározott tanulócsoport igényeihez igazodik, ezáltal sajátos célokat alakít ki. A nem-formális tanulás általában nem jár államilag elismert bizonyítvánnyal, oklevéllel, viszont az ismeretadás és -elsajátítás a formális tanuláshoz hasonló színvonalon is megtörténhet. Emellett a múzeum, az informális tanulás/oktatás színtere is lehet, hiszen a múzeumokban is megtörténhet/megtörténik, hogy a múzeumban eltöltött idő alatt észrevétlenül is végbemegy az ismeretszerzés és a tanulás. Ebben az esetben a múzeumban töltött idő és tevékenységek célja, nem kifejezetten a tudásszerzés, vagy a képzés, mégis az autodidakta tanulási folyamatban hasznos ismeretek, információk birtokába jut a látogató.

Az élménypedagógia térhódításával az iskolák egyre inkább nyitottabbakká váltak a tapasztalaton alapuló és a felfedezéses tanulás irányába (Mező, 2015), s ennek következtében a múzeumpedagógia is egyre nagyobb teret kaphat az iskolai oktatásban. Ez nem csupán egy lehetőség a tantermi oktatás kiegészítésére, de egyenrangú tudásforrást is jelent (Turbók, 2009; Kárpáti, 2011), hiszen az iskola által átadott tudásanyag összekapcsolódik a múzeum által felkínált élményanyaggal, amely ezáltal elősegíti az információk elmélyülését, megértését és hosszabbtávú rögzülését is.

A mú befogadásának minősége nagyban függ attól, hogy a látogató miként, milyen mértékben tudja átélni a befogadás és az alkotás örömét (Vásárhelyi és Kárpáti, 2011; Bíró, 2015). Ehhez néha elegendő a múzeum csendje által biztosított néma szemlélődés, de a köznevelés hatókörébe tartozó gyermekek és fiatalok általában nehezebben élik meg ezt a fajta elmélyülést. Sokkal inkább élvezik az interaktív, tapasztalti tanulást biztosító foglalkozásokat „mikor is a gyerekek önmaguk próbálhatják ki az eszközöket, a témához kapcsolódó játékos feladatok révén kísérletezhetik ki egy helyzet megoldását, majd saját tapasztalataik alapján önmaguk vonhatják le a következtetéseiket, fogalmazhatják meg a tanulságokat, és nem készen kapott ismereteket kell memorizálniuk. A gyerekek a foglalkozásokon nem passzív befogadók, hanem aktív résztvevők. Kérdeznek, vizsgálódnak, kísérleteznek, vitáznak, együttmúködnek." (Vágolva, 2013, 71.). Ilyen interaktív múzeumpedagógiai tevékenység lehet például, az interaktív tárlatvezetés; az alkotói tevékenységek, technikák kipróbálásának teret adó foglalkozások; a korokélethelyzetek bemutatása; ősi mesterségek felelevenítése; rajzok, festmények korhű reprodukciója; helytörténeti emlékek megtekintése; régi szokások felelevenítése; adott korban használt eszközök készítése; éjszakai múzeumi programok; nyílt 
napok; tematikus, projekt rendezvények stb. Emellett igen jelentősek a történelmi játszóházakban, emlékházakban, skanzenekben folyó hagyományőrző játékokok vagy a kézműves tevékenységek kipróbálására szervezett programok is (Mező, 2015).

Ezen jelenléti (kontakt) múzeumpedagógiai programok mellett, viszont egyre nagyobb teret élveznek a virtuális alapon szerveződő elképzelések.

\section{Virtuális Múzeum}

A virtuális múzeum intermediális alapon szerveződő digitális tér, mely lehetőséget biztosít a korábban megjelölt hagyományos múzeumi feladatok ellátására, valamint a digitális technológiák által nyújtott új lehetôségekkel való kiegészítésére. Ezáltal a számítógép, illetve az internet nyújtotta online, virtuális térben a valódi múzeumok szolgáltatását imitáló élmény nyújtható a felhasználóknak.

Az intermediális kifejezésen a technikai alapú információtovábbító eszközök összességét értjük: az írásnyomtatástól és a fotótól a filmen, magnón, a videón, a televízión, a számítógépen, az egyéb adathordozón át az internetig. Az intermediális kifejezés általános érvényű fogalom, mely a médiumok közötti összefüggésre utal.

A „virtuális” kifejezést legegyszerűbben, mint valami látszólagos, kézzel nem fogható, a valódit utánzó és annak tűnő képződményként értelmezhetjük. Egy virtuális objektumot a valódi helyett (részben vagy teljesen az eredeti funkciónak megfelelően) fogadunk el. Technológiai értelemben a „virtuális" kifejezés a valóság szimulációjára utal. A virtuális valóságnak többféle értelmezése van: 1) egyrészt úgy definiálható, mint számítógéppel vezérelt multiszenzoros kommunikációtechnológia, amely lehetővé teszi az intuitív interakciót az adatokkal, új módon bevonva az emberi érzékelést; 2) másrészt úgy is meghatározható, mint egy olyan, számítógéppel létrehozott környezet, amelyben a felhasználó is jelen van (Jacobson, 1993,1994; McLellan, 1997).

Egy virtuális múzeum múködhet önállóan (Mező és Mező, 2020), vagy egy hagyományos múzeum kiegészítő szolgáltatásaként. A virtuális valóságban működő múzeumnak előnyei és hátrányai is vannak a valódi intézményekkel szemben (1. táblázat). Az alábbiakban ezeket tekintjük át néhány szempont alapján.

Fenntarthatóság, müködtetés. A fenntartási és működési szükségletek és költségek terén a virtuális múzeum előnyösebb helyzetben van, a hagyományos, fizikai térben létező múzeumhoz képest. Ez utóbbi ugyanis feltételez például egy olyan ingatlant (egy skanzent magába foglaló telket és/vagy a kiállításoknak helyett adó épületet), ami rögtön több tíz, vagy akár százmilliós nagyságrenddel növeli az alapítási és fenntartási költségeket. Ez az ingatlanszükséglet a fizikai térbeli lehetőségeket is behatárolja - vagyis azt, hogy hol, mekkora területen, mennyire megközelíthető helyen, milyen várható látogatószámot generáló és egyéb turisztikai attrakciókkal szolgáló helyszínen, településen van az ingatlan, milyen lehetőség van a bővítésre, fejlesztésre. Az ingatlanvásárlással járó tetemes (igaz: egyszeri, vagy bérlés esetén többszöri) kiadást tovább növeli annak karbantartási, berendezési, víz-, gáz-, áramellátást igénylő üzemeltetési stb. költsége. Ezek a költségek nem merülnek fel (legalábbis ilyen nagyságrendben) a virtuális múzeumok esetében. A hagyományos múzeumok múködtetésének humán erőforrás szükséglete is nagyobb. Még ha azt feltételezzük is, hogy azonos létszámú muzeológus munkatárs rendezi a fizikai vagy a virtuális térben a kiállításokat, programokat stb., illetve végez kutatómunkát, azonos számú szakem- 
1. táblázat: a hagyományos és a virtuális múzeum összehasonlitása (forrás: a Szerzoőe)

\begin{tabular}{|c|c|c|c|c|}
\hline \multicolumn{2}{|c|}{ Összehasonlítási szempont } & \multirow{2}{*}{ Múzeum } & \multirow{2}{*}{\multicolumn{2}{|c|}{$\begin{array}{cc}\begin{array}{c}\text { Virtuális } \\
\text { múzeum }\end{array} \\
> & \bullet\end{array}$}} \\
\hline Fenntartási & Ingatlan: & & & \\
\hline szükséglet, & Gazdasági forrás: & $\bullet$ & $>$ & - \\
\hline \multirow[t]{2}{*}{ költségek } & Humán erőforrás: & ○ & $>$ & - \\
\hline & Informatikai: & - & $<$ & - \\
\hline A látogatót érő & Látványélmény: & $\checkmark$ & & $\sqrt{ } \mathrm{a}$ \\
\hline lehetséges & Hangélmény: & $\checkmark$ & & $\checkmark$ \\
\hline \multirow[t]{5}{*}{ élmények ${ }^{\mathrm{b}}$} & Tapintásélmény: & $\sqrt{ } \mathrm{b}$ & & $x$ \\
\hline & Illatélmény: & $\sqrt{ }$ b & & $x$ \\
\hline & Ízélmény: & $\sqrt{ } \mathbf{b}$ & & $x$ \\
\hline & Mozgásélmény: & $\checkmark$ & & $x c$ \\
\hline & Installációk:saját testméret arány élménye: & $\checkmark$ & & $x$ \\
\hline \multirow[t]{4}{*}{ Biztonság } & Látogatót/munkatársat érő baleset vagy fertőzés esélye: & ○ & $>$ & $\bullet$ \\
\hline & Installációkat érô sérülés esélye: & 0 & $>$ & $\bullet$ \\
\hline & Installációk eltulajdonításának esélye: & - & $<$ & 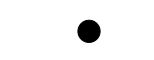 \\
\hline & Adatlopás esélye: & - & $<$ & ○ \\
\hline \multirow[t]{4}{*}{ Szolgáltatások } & Állandó kiállítások & $\checkmark$ & & $\checkmark$ \\
\hline & Időszaki kiállítások & $\checkmark$ & & $\checkmark$ \\
\hline & Tárlatvezetések & $\checkmark$ & & $\checkmark$ \\
\hline & Múzeumpedagógia: & $\checkmark$ & & $\checkmark$ \\
\hline Kiegészítő & 24 órás nyitva tartás: & ?d & & $\checkmark$ \\
\hline szolgáltatások & Ajándékbolt: & $\checkmark$ & & $\sqrt{ } \mathrm{e}$ \\
\hline
\end{tabular}

a 3D installációk új nézőpontból (például felülnézetből) történő megtekintése is lehetséges.

b Megjegyzendő, hogy a kiállítási tárgyak megérintése sok esetben tilos (ilyen esetekben a tapintással kapcsolatos élményeket a hagyományos múzeumban sem szerezhet a látogató), az üvegtárlókba zárt tárgyaknak nem érződik az illata, a kiállítási tárgyak megkóstolása (ital- és ételkiállítások ritka kivételétől eltekintve) nem jellemző...

c Kinekt-szerü technológián alapuló virtuális múzeumban a mozgásélmény (például a kiállításon történő séta élménye) is biztosítható.

d A 24 órás nyitva tartás elvileg lehetséges a hagyományos múzeumok esetében, de nem jellemző.

e Virtuális múzeum esetében webáruház valósíthatja meg az ajándékbolt jellegü szolgáltatást

ember gárda szervezi és valósítja meg a múzeumpedagógiai foglalkozást, a teremfelügyelet és a takarítás mégis olyan kiadásokkal jár, amelyek a virtuális múzeumok esetében nem jellemzők. Összességében tehát a virtuális múzeumok múködtetéséhez lényegesebben kevesebb gazdasági erő- forrásra van szükség. Az informatikai feltételeket tekintve azonban könnyen belátható módon a virtuális múzeumok igényelnek nagyobb hardver, szoftver és az azokat üzemeltetni képes humán erőforrásokat. 
A látogatói élmény. Költséghatékonyságuk ellenére a múzeumlátogatók, illetve a múzeumpedagógiai foglalkozásokon résztvevők számára nyújtott élmények tekintetében a virtuális múzeumok maradnak alul az összehasonlítás során - bár bizonyos esetekben még ez is vita tárgya lehet! A virtuális múzeumok 2D (például: térképeket, fotókat, illusztrációkat stb.) és 3D (például: fegyvereket, ruházatokat, terepasztalokat bemutató) installációkat éppúgy be tudnak mutatni, mint a hagyományos múzeumok (1. ábra). Látványélmények tekintetében ráadásul a virtuális múzeumok új dimenziókat nyújthatnak a kiállított tárgyak, alkotások megismerése tekintetében akkor, ha a látogató olyan nézőpontból is megtekintheti azokat, amelyekre a fizikai térben esetleg nincs lehetősége (például felülnézetből szemlélheti egy szoborkompozíció elrendezését). Továbbá egy-egy részletre történő ráközelítésre is olyan módot adhat a számítógépes élmény, amelyre az épített kiállítási terekben kordon mögül szemlélt alkotások esetében nincs mód. A tudnivalókat kommentáló feliratok, információk is látványosabbak lehetnek a virtuális térben. Az azonban vitathatatlan, hogy aki eredeti műalkotást szeretne látni, annak a virtuális múzeum nem adhatja meg a kívánt műélményt (kivéve: ha eleve virtuális alkotásról, például számítógépes grafikáról, animációról stb. van szó).

1. ábra: 2D és 3D installációk is bemutathatók egy virtuális múzeumban (forrás: a Szerzóke)

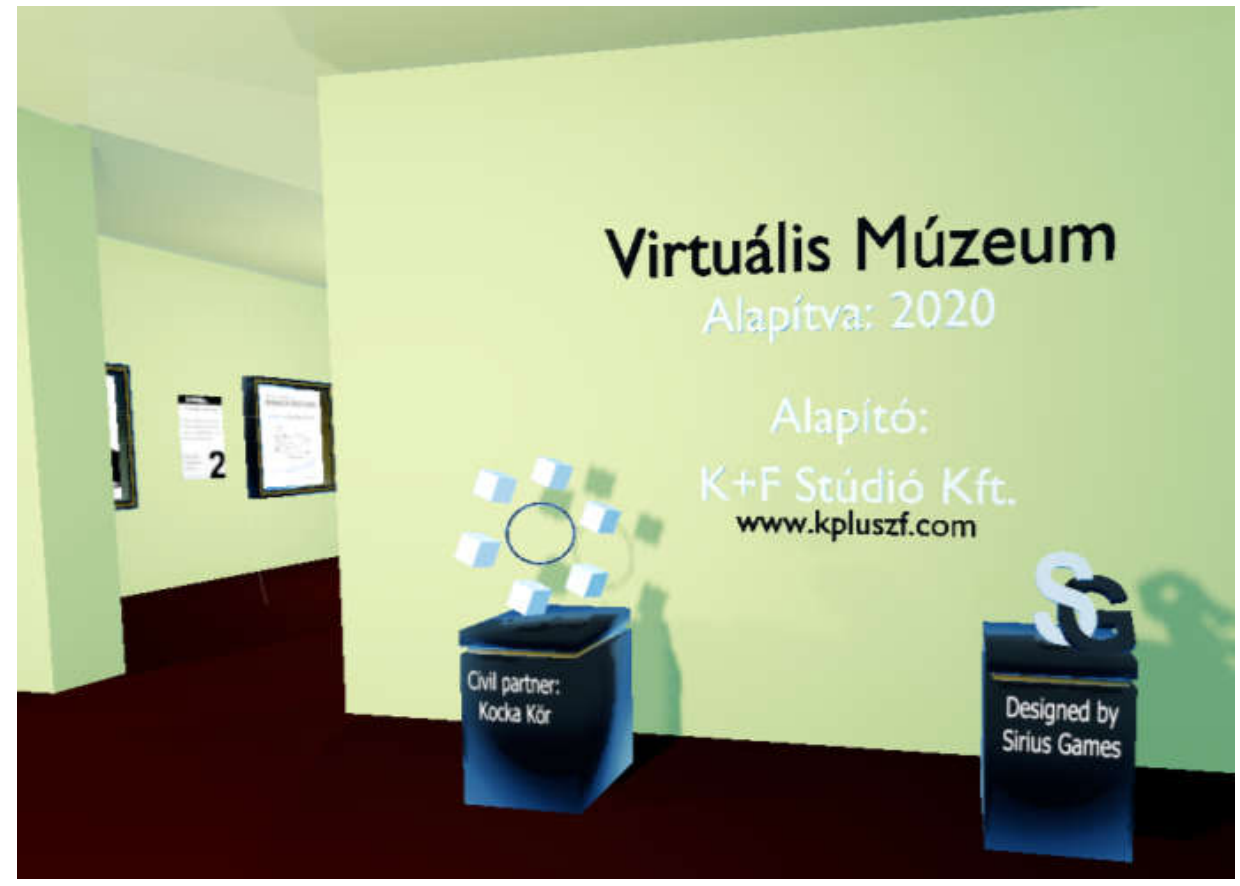

Az akusztikus ingerek tekintetében a digitális technika az ismételhetőségen és a látogató által kívánt időpontban történő lejátszáson túl a hangerő, a hangmagasság, a tempó és a lejátszási irány felhasználó által történő megválasztásában nyújthat lehetőségeket az interaktív élményszerzésre. Ugyanakkor az is tény, hogy aki igazi madárfüttyöt akar hallani, vagy aki egy vízimalom működésével járó vízcsobogást eredetiben szeretne élvezni, annak egy skanzen nyújthat megfelelő auditív élményt (persze 
csak akkor, ha a madár is úgy akarja, és a vízimalom is múködik éppen). Az installációkról szóló ismeretközlő szövegek ismételt, a felhasználó számára megfelelő hangerőn (esetleg tempóban) és nyelven történő lejátszására is lehetôséget adhat egy virtuális múzeumbeli tárlatvezetés, -látogatás.

Tapintás-, illat- és ízélményt sem nyújthat (egyenlőre!) a rendelkezésre álló informatikai technológia egy virtuális múzeum látogatói számára. Tény azonban, hogy a legtöbb esetben a hagyományos múzeumokban sem megengedett a kiállított tárgyak megérintése és megízlelése (az étel- és italbemutatók kivételével), s valójában azok illata is elérhetetlen élmény a látogatók számára, ha a kiállított darabok üvegvitrinekbe, tárlókba vannak zárva. Megjegyzendő, hogy a már napjainkban is rendelkezésre álló 3D nyomtatási technológia révén térbeli múalkotások és egyéb kiállitási tárgyak (például: csontok, kövületek, növény- és állatreprodukciók stb.) kisebb-nagyobb reprodukciói is létrehozhatók, amelyek például nem látó embertársaink számára is megismerhetőbbé (szó szerint kitapinthatóbbá, megfoghatóbbá) teszik a kiállitást. Az illat- és ízélményeket biztosító technológia is várható a jövőben (lásd példaul: illatélményeket is nyújtó 4D filmvetítések esetét).

Egy múzeum/skanzen bejárása olyan mozgásélményt jelenthet, amivel egy virtuális múzeum nem versenyezhet. Ugyanakkor: már napjainkban rendelkezésre áll az a technológia, amely révén a virtuális térben valódi fizikai mozgás révén haladhatunk. Ilyen például a játékok világából közismertté és sokak által elérhetôvé vált kinekttechnológia. Másrészt az is igaz, hogy a megszokott fizikai környezetből (otthonról, iskolából stb.) történő kimozdulás élményét a valódi múzeumok látogatása biztosítja igazán.

Amit a virtuális múzeum még sokáig nem fog tudni megadni, az az „installáció: saját testméret” arány élménye. Hiába jeleníthetók meg egymás mellett a virtuális világban a látogatók avatarjai (a látogatókat a virtuális világban szemléltető karak- terek) és a bemutatásra szánt tárgyak akár méretarányosan is, mégsem lesz ugyanaz az élmény, mint amit a valóságban tapasztalhatunk meg. Például: a piramisok mellett állva tapasztalhatjuk meg azok valóban lenyűgöző nagyságát. Vagy: a miniatűr könyvek parányi méretét is akkor érzékeljük igazán, amikor a feléjük tartott tenyerünk méretéhez hasonlítjuk azt.

Bižtonság. Baleset- és egészségvédelmi szempontból a virtuális múzeumok megint csak előnyben vannak a hagyományos múzeumokhoz képest. A látogatókat és a munkatársakat érő baleset és fertőzés veszélye minimális a virtuális múzeumok esetében.

A fertőzés veszélye, illetve annak elhárítása a COVID-19 vírus által 2020ban előidézett világjárvány időszakában vált nemzetközi szinten is különösen lényeges biztonsági tényezővé.

Nem hagyható figyelmen kívül ugyanakkor, hogy a képernyő elôtt történő ülésből származó testtartás, illetve a szemet érô terhelés, vagy túlzott hangerô esetében a fület érő hatások, akár maradandó egészségkárositó ártalmakkal is járhatnak. Az installációkat érô sérülés veszélye felől közelítve a biztonság kérdéséhez, újra a virtuális múzeumok vannak előnyös helyzetben. Azonban az adatlopás, az installációk eltulajdonításának esélye sokkal nagyobb a virtuális térben, mint a valóságban.

Múzeumi szolgáltatások. Állandó és idôszakos kiállítások, tárlatvezetés és múzeumpedagógiai szolgáltatás a hagyományos és a virtuális múzeumokban is megvalósíthatók (bár az utóbbiakban költséghatékonyabban, nagyobb látogatószámot is kezelni képes módon). A tárlatvezetés és a múzeumped- 
agógiai foglalkozás pedig megoldható szoftver révén vagy adott esetben élőszeméllyel történő online kommunikáció révén is. Mindkét múzeumi forma esetében lehetôség van arra, hogy a hagyományos ismeretközlő, tájékoztató, értékközvetítő és nevelő funkciót erősítő interaktív feladatokkal, kihívásokkal is találkozzanak a látogatók (ezek között egyaránt megtalálhatók lehetnek például kvízjátékok, ügyességi játékok, stratégiai fejtörők, stb.).

Kiegészító szolgáltatások. A múzeumélményhez társuló kiegészítő szolgáltatások közé soroljuk itt a 24 órás nyitva tartást vagy akár a múzeumi ajándékboltok múködtetését. Az egész napos nyitva tartás elvileg a hagyományos múzeumok esetében is lehetséges lenne, azonban ritkán valósul meg. Egy virtuális múzeum ezzel szemben valóban napi 24 órában tudja fogadni és kiszolgálni látogatóit. Múzeumpedagógiai szolgáltatást is nyújthat egy múzeum (rendszerint előre bejelentkezett és korlátozott létszámú csoportok számára). A múzeumpedagógiai szolgáltatásban részesülő látogatók számát tekintve a virtuális múzeum előnyösebb helyzetben lehet: oktatószoftvereit a világ bármely részérôl jóval nagyobb számú látogató veheti igénybe. A múzeumi élményhez tartozhat a szuvenír vásárlás is az intézmény ajándékboltjából. Az így származó bevétel pedig hozzájárulhat a fenntartási költségek fedezéséhez és/vagy a nyereségtermeléshez.

Egy kisköltségvetésú virtuális múzeumhoz kapcsolódó webáruház ugyanakkor hasonló vagy nagyobb kereskedelmi forgalmat mondhat magáénak, mint egy hagyományos (nagy fenntartási és árubeszerzési költségekkel működő) ajándékbolt.

\section{Múzeumpedagógiai lehetőségek egy virtuális múzeumban}

A múzeum és az iskola együttműködése többek között a szórakoztatva tanulás kapcsán valósulhat meg (Csesznák, 2009). A lexikális ismereteket átadó tanítás/tanulás mellett további - a tehetséggondozó programokban is népszerú - pedagógiai lehetôségeket is rejtenek a múzeumok, így a virtuális múzeumok is.

Az alábbiakban röviden felvetünk néhány lehetôséget egy virtuális múzeumban megvalósítható, gazdagító jellegû́ tehetséggondozó foglalkozás (sorozat) jellegzetes céljaival kapcsolatban. A dúsító, gazdagító tehetséggondozó programokban (is) alkalmazható öt pedagógiai célkitűzés (Mező, 2012 alapján): 1) ismeretközlés, 2) képességfejlesztés, 3) személyiségfejlesztés, 4) módszertan átadás, 5) teljesítményre ösztönzés.

\section{Ismeretkö̃lés}

Egy virtuális múzeum (is) alkalmas lehet jóformán bármely tantárgy, bármely tananyagának átadására - a kiállítás témájától függően. Az ismeretátadást célzó pedagógiai tevékenység olyan jellegzetes tevékenységei is megvalósíthatók egy virtuális múzeum keretein belül, mint az előzetes tudás felmérése, a tananyag prezentálása, a tananyag interaktív gyakoroltatása, a megszerzett tudás ellenőrzése és diagnosztikus/formatív vagy szummatív értékelése.

Virtuális múzeumi környezetben megvalósítható, tudásszintet felmérő feladat instrukciója lehet például: „Üdvözlünk a Virtuális Múzeum raktárában! A feladatod az, hogy: 1) az itt található kiállitási anyagok közül válaszd ki azt a 10-et, ami a legszorosabban kapcsolódik a ... témához, 2) írj hozzájuk rövid ismertetô szöveget, ami minél több tényszerű információt tartalmaz (ehhez semmilyen segédletet nem használhatsz, csak a saját tudásodat) vagy egészítsd ki a Virtuális Múzeum munkatársai által megkezdett szövegeket, s írd be a hiányzó szakkifejezéseket, adatokat!"

A tananyag prezentálása lényegében egy Virtuális Múzeumban megtett olyan látogatás, ahol a tanári/ tankönyvbeli információkat a virtuális múzeum tárlatainak audiovizuális magyarázó szövegei és installációi helyettesítik. Az ilyen feladat egy le- 
hetséges instrukciója például: „Üdvözlünk a Virtuális Múzeumban! Egy új témakör tanulásába kezdünk, aminek a címe: ... . Kérünk, hogy a tananyagot a Virtuális Múzeum látogatása során sajátítsd el. Minden szükséges információt megtalálsz a kiállításon. Jó munkát, izgalmas élményeket kívánunk!"

Egy Virtuális Múzeumbeli látogatás során a tananyag interaktív gyakoroltatása az installációkkal és vagy a teljes kiállítással kapcsolatban készített, a látogató aktív ténykedését feltételező, arra reagáló szoftverek révén valósítható meg. E szoftverek (oktató programok) lényegében lehetôvé tehetik a programozott oktatás megvalósítását is.

$\mathrm{Az}$ oktató szoftverek továbbá az ismeretelsajátítást is ellenőrizhetik, arról gyors és személyre szabott visszajelzést adhatnak (akár magyarázhatnak is) a felhasználóknak (például: diáknak, szülőnek, pedagógusnak, tananyag- és/vagy szoftverfejlesztőnek stb.), és formatív, illetve szummatív értékelés során is hasznosíthatók lehetnek.

\section{Képességejlesztés}

Egy Virtuális Múzeumban - fóként kognitív képességfejlesztés is megvalósítható. Egy önkontrollos hatásvizsgálattal biztosított képességfejlesztés során egy Virtuális Múzeum alkalmas lehet például:

a) elôvizsgálatra: lényegében témafüggetlen képességvizsgáló feladatok is közreadhatók egy Virtuális Múzeumbeli látogatás során, amelyek (ha nem is klinikai igényú, de mindenesetre információértékû) adatokat szolgáltatnak a tanulók megismerése szempontjából a képességfejlesztést tervező/végző szakember(ek) számára. A diagnosztikai szoftver adaptív teszteljárásokat is alkalmazhat, ami lehetővé teszi a vizsgált személy képességeinek alaposabb feltérképezését. Az elővizsgálat eredményeként a Virtuális Múzeumbeli látogatás eredménye konkrét fejleztési terv is lehet.

b) fejlesztő gyakorlatok összeállítására, interaktív gyakoroltatására: akár gamifikált formában is megvalósítható képességfejlesztés is elképzelhető egy Virtuális Múzeum révén. A fejlesztő feladatok értékelését, összegzését és a fejlesztési terv szükség szerinti módosítását is lehetôvé tehetik az alkalmazott szoftverek.

c) utóvizsgálatra: a fejlesztés hatékonyságáról informál utóvizsgálat feladatai is közreadhatók egy Virtuális Múzeumbeli látogatás során. Az adatfelvétel mellett az eredmények értékelése és előviszgálattal történő összevetése is lehetséges, valamint a további fejlesztéssel kapcsolatos tanács, stratégia is megfogalmazható.

\section{Személyiségfejlesztés}

A képességfejlesztéshez hasonlóan a minimum önkontrollos hatásvizsgálattal biztosított személyiségfejlesztésnek is legalább három komponense van: elővizsgálat-fejlesztés-utóvizsgálat. Egy Virtuális Múzeum (vagy annak egy tárlata) tartalmi szempontból összeállítható úgy is, hogy (akár adaptív feladatok, információk adásán keresztül) önismereti, önértékelési információkhoz segítse a látogatókat, direktív vagy nondirektív tanácsadást valósítson meg (nem klinikai esetekben), illetve (múködését egy jelző rendszer egyik első állomásaként értelmezve) pszichológiai, pszichiátriai kezelést javasoljon adott esetben. Egy Virtuális Múzeumban lehetôség van továbbá a szorongással, az agresszióval, a bántalmazással stb. való megküzdési technikák, preventív és interventív lehetőségek bemutatására, a látogató korának ismeretében akár szoros értelemben vett kortársak eseteinek bemutatására stb.

\section{Módszertan átadás}

Tanulásmódszertan, lázmérés, egyszerű ételek elkészítése, tájékozódás csillagok alapján, harcmúvészeti mozdulatsor elsajátítása, stb. - ezek mind módszertani, gyakorlati jellegű témakörök, amik elsajátításába, gyakoroltatásába például egy Virtuális Múzeum is segíthet. A kiállitás látogatása alkalmával (lényegében tetszőleges ismétlésszám- 
ban, ráközelítéssel, lassítással stb.) mutatható be egy-egy adott módszertani fogás (legyen az a lázmérô bekapcsolása vagy egy adott testtartás/mozdulat, amivel tompítható az esésekkel járó ütődés egy harcmúvészeti edzésen, stb.). Ellenőrizhető a cselekvési séma megléte, minősége. Visszajelzés adható a felhasználónak arról, hogy az adott módszertant milyen biztonsággal használja.

\section{Teljesitményre ösztönzés}

A tehetséggondozó programok egy köre teljesítményekre (például: könyvek, szakcikkek, novellák, versek, grafikai alkotások, festmények, szobrok, koreográfiák, zenemúvek, zenei előadások, innovációk stb. alkotására) igyekszik ösztönözni a bevont személyeket. Egy Virtuális Múzeum esetében nemcsak a hagyományos teljesítményre ösztönző felhívások tehetők meg (például: versmondó-, ének-, rajzversenyek stb. hirdethetők meg), hanem akár egy virtuális tárlat megtervezésére is lehetőség van. A Virtuális Múzeum szoftvere pedig alkalmassá tehető a személyes teljesítmények regisztrálására, s azok alapján akár a teljesítményekről szóló igazolások automatikus előállitására is.

\section{ZÁRÓGONDOLATOK}

Miként a múzeumok mintájára virtuális múzeumok hozhatók létre, úgy a múzeumpedagógia mintájára virtuális múzeumbeli (de valódi!) pedagógia is megvalósítható. A virtuális múzeumok létrehozása és múködtetése sok szempontból (például: gazdasági, foglalkoztatási, biztonsági stb. aspektusból) olcsóbb és egyszerúbb, mint ami a valódi múzeumok esetében tapasztalható. Ugyanakkor az „otthonról” (értsük bár ezalatt a látogató saját szobáját, tantermét, intézményét, városát stb.) való kimozdulás élménye, a saját testhez történő viszonyítás élménye és néhány érzékszervi élmény tekintetében a valódi múzeumok többet nyújtanak napjainkban, mint a virtuálisak. Semmiképpen nem egészséges versenyeztetni a két múzeum típust, azonban jelen tanulmány szerzői úgy vélték, hogy újszerűsége miatt hasznos lehet a virtuális múzeumokban rejlő pedagógiai lehetőségekre, esetleges veszélyekre felhívni a figyelmet.

\section{Irodalom}

1997. évi CXL. törvény a muzeális intézményekeról, a nyilvános könyvtári ellátásról és a közmüvelödésröl. Letöltés: 2020. 01.12. Web:

https://net.jogtar.hu/jogszabaly?docid=997001 40.tv

2012. évi CLII. törvény a muzeális intézményekről, a nyilvános könyvtári ellátásról és a közművelődésről szóló 1997. évi CXL. törvény módosításáról. Letöltés: 2020.08.16. Web: https://net.jogtar.hu/jogszabaly?docid=a12001 $\underline{52 . t v}$

2017. évi LXVII. törvény a muzeális intézményekről, a nyilvános könyvtári ellátásról és a közmúvelődésről szóló 1997. évi CXL. törvény és egyes kapcsolódó törvények módosításáról. Letöltés: 2020.08.16. Web: https://net.jogtar.hu/jogszabaly?docid=A1700 067.TV\&txtreferer $=00000001$. TXT

Bíró Éva (2015). Múzeum, múvészet, pedagógia. Magyar Múzeumok - A Pulszky Társaság Magyar Múzeum Egyesület Online magazinja. Letöltés: $\quad 2019.06 .20$. Web: http://archiv.magyarmuzeumok.hu/muhely/28 72_muzeum_muveszet_pedagogia. Csesznák Éva (2009). Múzeum és iskola együttműködése. In: Szórakoztatva tanulni, tanulva srórakozni! Projektmódszer a múzeumpedagógiában, Oktatási segédanyag. Szabadtéri Néprajzi Múzeum Múzeumi Oktatási és Képzési Központ, Szentendre, 18-20.

Jacobson, L. (1993). Welcome to the virtual world. In Richard Swadley (Ed.). On the cutting edge of technology. Carmel, Sams. 69-79.

Jacobson, L. (1994). Garage virtual reality. Carmel, Sams. 
Kárpáti Andrea (2011). A múzeumi kiállítás mint tanítási és tanulási környezet. In: Kárpáti Andrea, Vásárhelyi Tamás, Múzeumi tanulás. Typotex Kiadó, Budapest, 38-42.

McLellan, Hilary (1997): Virtual Realities. In Jonassen, David, Driscoll, Marcy (Eds). Handbook of Research on Educational Communications and Technology. A Project of the Association for Educational Communications and Technology. Routledge, New York. 17-37

Memorandum az egész életen át tartó tanulásról (2000) Európai Közzösségek. Bizottsága. A Memorandum on Lifelong Learning. Letöltés: 2019.01.20. web: https://arhiv.acs.si/dokumenti/Memorandum on Lifelong_Learning.pdf

Mező Ferenc (2012). A tehetséggondozás koordinálása In Mező Ferenc (szerk.). Tehetségkoordinátorok kézikeönyve. $\mathrm{K}+\mathrm{F}$ Stúdió Kft., Debrecen. 71-82.

Mező Ferenc és Mező Kristóf Szíriusz (2020): Virtuális Múzeum adhat helyet a lélektani hadviselés példatárának. Lélektan és hadviselés - interdiszziplináris folyoirrat, II. évf. 2020/1. szám. 113-114.

Mező Katalin (2015). Kreativitás és élménypedagógia. Kocka Kör Tehetséggondozó Kulturális Egyesület, Debrecen
Ortutay Gyula (1980). Magyar Néprajzi Lexikon, 3.kötet. Akadémiai Kiadó, Budapest. http://www.mek.oszk.hu/02100/02115/html/ $\underline{3-1955 . h t m l}$

Swiderkowna, Anna (1981). A bellenizmus kultúrája. Gondolat Kiadó, Budapest.

Trencsényi-Waldapfel Imre (1983). Mitológia. Gondolat Kiadó, Budapest.

Turbók Arnold Bertalan (2009). A kompetencia alapú képzés és a múzeum - mint az egész életen át tartó tanulás alapja. In: Szórakoztatva tanulni, tanulva szórakozni! Projektmódszer a múzeumpedagógiában, Oktatási segédanyag. Szabadtéri Néprajzi Múzeum Múzeumi Oktatási és Képzési Központ, Szentendre, 16-18.

Vágolva Éva (2013). A tanórán kívüli oktatás és az élménypedagógia pszichológiai, pedagógiai szempontjai és elónyei. Levéltári Sžemle, 63, 4, 61-71

Vásárhelyi Tamás, Kérpáti Andrea (2011). Múzeumi tanulás. MTM-Typotex, Budapest. 